Check for updates

The BMJ

Cite this as: $B M J 2020 ; 371:$ m3804 http://dx.doi.org/10.1136/bmj.m3804 Published: 01 October 2020

\section{Covid-19: NHS staff must be tested weekly to keep services running, say MPs}

\section{Gareth lacobucci}

The government should ensure that all NHS staff are routinely tested for covid-19 this winter to enable services to continue, a committee of MPs has urged.

In its inquiry report into the impact of the pandemic on core services, the House of Commons Health and Social Care Committee said that urgent action was needed to tackle a treatment backlog and an unknown level of demand for all health services. ${ }^{1}$ It said particular attention was needed in cancer care, mental health services, dentistry, general practice services, and elective surgery.

The report said that a "compelling case" had been made for rolling out routine testing of all NHS staff. The MPs said that they had accepted advice from scientists that there was "a significant risk that not testing NHS staff routinely could lead to higher levels of nosocomial infections in any second spike" and had asked the government why routine testing was not already in place.

The committee chair Jeremy Hunt said, "Weekly testing of NHS staff has been repeatedly promised in hotspot areas-but is still not being delivered. Failure to do so creates a real risk that the NHS will be forced to retreat into being a largely covid-only service during a second spike. We've heard of severe disruption to services, especially cancer, and here we could be looking at tens of thousands avoidable deaths within a year. If we're to avoid this going forward it is time to give as much priority to avoiding harm and death caused by the interruption of normal NHS services and introduce mass testing for all NHS staff.”

The report said that the government and NHS England must set out by the end of October what they require to be able to offer routine tests to all NHS staff nationwide. Routine staff testing must be rolled out "as quickly as capacity allows, [and] certainly before winter," it said.

The committee, which heard evidence from royal colleges, medical leaders, NHS bosses, think tanks, and patient groups, also raised concern at the "mismatch" between the instruction from NHS England not to stop cancer services during the pandemic and evidence it received that cancer services had been "severely disrupted."

The report criticised the government and the NHS for "poor communication" over the availability of care during the pandemic, leading to "unnecessary anxiety and stress" for patients. "For some the patient experience had been unacceptably poor, leaving them feeling left "in the lurch,"' it said and urged NHS England and NHS Improvement to review its advice to local NHS trusts about how to communicate with patients about the progress of their treatment.
The report emphasised the importance of a “consistent and reliable" supply of appropriately fitting personal protective equipment to all NHS staff in advance of winter and a potential second wave, as the government promised earlier this week. ${ }^{2}$

Ruth Thorlby, assistant director for policy at the Health Foundation, said that the recommendation for staff testing was logical but cautioned, "It is far from clear that testing capacity exists to enable this. home staff earlier this month but testing in social care has been beset with problems, with reports of tests in some areas either unavailable or results

\section{House of Commons Health and Social Care Committee. Delivering core NHS and care services during the pandemic and beyond. Second Report of Session 2019-21. https://committees.parliament.uk/committee/81/health- and-social-care-committee. \\ 2 lacobucci G. Covid-19: Government promises an "uninterrupted. BMJ 2020;370:m3784doi: 10.1136/bmj.m3784.}

This article is made freely available for use in accordance with BMJ's website terms and conditions for the duration of the covid-19 pandemic or until otherwise determined by BMJ. You may use, download and print the article for any lawful, non-commercial purpose (including text and data mining) provided that all copyright notices and trade marks are retained. The government committed to weekly testing of care delivered too late." 